\title{
Epidemiology of khat (Catha edulis) consumption among university students: a meta-analysis
}

\author{
Getinet Ayano ${ }^{1 *}$, Kalkidan Yohannis ${ }^{2}$ and Mebratu Abraha ${ }^{3}$
}

\begin{abstract}
Background: Khat is amphetamine-like substance commonly consumed by students when they wish to study for long hours especially during examination periods. Khat consumption is associated with increased rates of cardiovascular problems, stroke, myocardial infarction, cardiomyopathy, periodontal disease, gastritis, poor oral hygiene, psychosis, decreased quality of life, and poor academic performance.

Methods: PubMed, EMBASE, and SCOPUS were systematically searched without restriction by publication status. Publications were screened according to predefined inclusion criteria. Twenty-five articles were included. Random effect model was used to calculate weighted prevalence, odds ratio (OR) and corresponding 95\% confidence interval (Cl). We assessed the risk of publication bias by using funnel plot and Eggers's regression tests.

Results: The pooled prevalence of current khat use among university students was $14.16 \%$ (95\% Cl; 11.87-16.81). The pooled prevalence of current khat use was highest in Saudi Arabia 18.85\% and it was 13.59\% in Ethiopia and $13.04 \%$ in Yemen. In addition, the current pooled prevalence of khat use was higher in men at $19.26 \%$ than in women $6.41 \%$. Regarding lifetime khat use, in this study, the pooled prevalence of lifetime khat use was $27.31 \%$. The lifetime prevalence was higher in men at $31.47 \%$ than in women $11.79 \%$. Moreover, the lifetime prevalence of khat use was 43.27\% in Yemen, 37.32\% in Saudi Arabia, and 24.82\% in Ethiopia. We found significantly increased odds of current (OR 3.59; 95\% Cl 2.01-6.41) as well as lifetime (OR 3.48; 95\% Cl 2.09-5.78) khat chewing in men as compared to women.

Conclusion: The pooled prevalence of current and lifetime khat consumption was 14.16 and $27.31 \%$, respectively. Both the current and lifetime prevalence of khat use was higher in men than in women. In addition, both the current and lifetime prevalence estimates of khat consumption were low in Ethiopia than in Saudi Arabia. Moreover, the odds of both current and lifetime khat consumption were higher in male students than in female students. Programmes that specifically aim at increasing awareness and that most motivate reduced khat consumption among university students were recommended.
\end{abstract}

Keywords: Epidemiology, Khat use, University students, Meta-analysis

\footnotetext{
* Correspondence: babiget2015@gmail.com

${ }^{1}$ Research and Training Department, Amanuel Mental Specialized Hospital,

POBOX: 1971, Addis Ababa, Ethiopia

Full list of author information is available at the end of the article
}

(c) The Author(s). 2019 Open Access This article is distributed under the terms of the Creative Commons Attribution 4.0 International License (http://creativecommons.org/licenses/by/4.0/), which permits unrestricted use, distribution, and reproduction in any medium, provided you give appropriate credit to the original author(s) and the source, provide a link to the Creative Commons license, and indicate if changes were made. The Creative Commons Public Domain Dedication waiver (http://creativecommons.org/publicdomain/zero/1.0/) applies to the data made available in this article, unless otherwise stated. 


\section{Background}

Khat (Catha edulis) is "amphetamine-like" substance or stimulant which is consumed widely in some parts of Africa as well as Arabian Peninsula and Diaspora communities from these countries $[1,2]$. In some countries located in Africa and the Arabian Peninsula, chewing the leaves of khat is socioculturally embedded and commonly practiced mainly due to its stimulating property [2, 3].

For those people living in some societies in Yemen and other east African countries chewing the leaves of khat is acceptable and habitual practice particularly among Muslims [4, 5]. The fresh leaves of khat are chewed daily on regular basis mainly in the afternoon, although starting in the morning is seen in some people. In addition, chewing khat is more popular in some social gatherings such as funerals and wedding election time and wedding parties.

Epidemiological evidence showed that khat consumption is associated with an increased rates of cardiovascular problems [6-8], stroke [9-11], myocardial infarction and cardiomyopathy $[12,13]$, periodontal disease, stomatitis, esophagitis and gastritis [14, 15], periodontitis, gingivitis and poor oral hygiene [16-19], psychosis [20, 21], decreased quality of life [22], and poor academic performance [23, 24].

Khat consumption is also a common practice among university students [6]. University students commonly chew khat when they want to study for long hours mostly during examination periods [25]. According to scientific evidence, there is a recent increase in the consumption of khat among university students. For example, in one study conducted among male students of Aden University, the prevalence of khat chewing increased from 35 to $90 \%$ in 5 years [26]. In other study conducted in Saudi Arabia among students of age 15 to 25 years, the prevalence of khat consumption was found to be $37.7 \%$ among male students compared to only $3.8 \%$ among females [27]. In one of Ethiopian study conducted in Addis Ababa, 15.9\% of male students regularly chew khat [6].

In view of the above issues, we undertook a meta-analysis of published observational studies conducted among university students on khat use to systematically investigate: [1] the prevalence of current and lifetime hat use, [2] the existing differences in the risk of khat consumptions between men and women, and to formulate recommendations for future research.

\section{Methods}

A systematic literature search was conducted following the "Preferred Reporting Items for Systematic Reviews and Meta-Analyses (PRISMA)" guidelines [28]. We consulted three databases (EMBASE, PubMed, and Scopus) for our search. We searched PubMed using the following terms and keywords ((khat OR Catha edulis OR khat use OR khat consumptions OR khat chewing OR khat abuse OR khat dependence OR khat use disorder OR substance OR substance use OR psychoactive substance OR substance use disorder OR substance abuse)) AND (student OR university student OR college student). For the remaining two databases (EMBASE and Scopus) we used specific subject heading related to the above keywords employed in PubMed. The citations retrieved from each database were saved in our endnote library at the moment of searching. After completing the search for each database, we imported the completed citations from the three databases into a unique EndNote library and saved after excluding duplicates for this research. We also scanned the reference lists of eligible studies to identify additional studies of relevance to this review. In addition, we looked manually to discover possible relevant published as well as grey literature.

\section{Eligibility criteria}

Studies meeting the following criteria were included in this meta-analysis: First, the observational study in design type (including cross-sectional and case-control study design); second, the outcome of interest was either khat use (current and lifetime use) or khat dependence among university students; third reported the magnitude of khat use and dependence and determined the risk khat use for male and female university students. Moreover, we excluded commentaries, reviews, editorials, and studies not published in the English language. Two investigators (GA and MA) screened the relevance of the studies based on their title and abstract before the retrieval of full-text articles. Then the full-text articles were further evaluated them for their eligibility independently by two investigators (GA and MA). We resolved disagreements by discussing with the third investigator (KY).

\section{Methods for data extraction}

We utilized a standard data extraction form to identify relevant data from full-text studies included in our meta-analysis. Two investigators (GA and MA) independently extracted the data. We extracted the following information: first author's last name, country, a sample size of the participants, year of publication, study setting (community, clinical or institution), instrument used for measuring outcome, and the prevalence of khat use and dependence.

\section{Methods for data analysis and quality assessment}

We used a random-effect model to calculate the pooled prevalence, odds ratios and 95\% CIs in our meta-analysis [29]. Comprehensive meta-analysis software version3 was used for analysis. We used Cochran Q and the $\mathrm{I}^{2}$ statistics to evaluate the presence of heterogeneity [29]. The magnitude of $I^{2}$ statistic values such as 25, 50 and 
$75 \%$ was used to show low, medium and high heterogeneity, respectively [30]. We evaluated the quality of the studies included in our meta-analysis using the Newcastle-Ottawa scale (NOS) with modifications [31]. The main domains of the NOS include the representativeness of the sample size of the participants, the measurements of khat use, comparisons between the participants and quality of statistical analysis. During the quality assessment, the agreement between the two investigators (GA and MA) was evaluated by using agreement beyond chance (unweighted Kappa). The values 0 , $0.01-0.20,0.21-0.40,0.41-0.60,0.61-0.80$, and $0.81-1.00$ were used to represent poor, slight, fair, moderate, substantial, and almost perfect agreements, respectively [32].

We assessed the risk of publication bias by using funnel plot and Eggers's regression tests.

\section{Results}

\section{Study selection}

The electronic search identified 14,998 articles. Additionally, we identified eight citations through a manual search of the reference lists of the remaining articles. A total of 14,960 were excluded based on the review of the abstract, titles and duplicate as they did not meet the inclusion criteria (Fig. 1). Then, the full text of 46 articles was retrieved for further screening and 21 of these were excluded. Finally, 25 articles that qualified the inclusion criteria were included in this study.

\section{Study characteristics}

The characteristics of studies included in this meta-analysis were indicated in Table 1 . In this meta-analysis, a total of 24,136 participants from 25 studies were included in the analysis. Selected studies were conducted between 2002 and 2017. All studies included in our analysis used a cross-sectional study design to determine khat use among university students. Most of the studies reported response rate. Most of the studies were conducted in Ethiopia $(n=19)$ [25, 33-50] and the others were conducted in Saudi Arabia $(n=3)$ $[27,51,52]$, Yemen $(n=3)$ [53-55] (See Table 1). Of the included studies, 18 of the studies assessed current khat use and 21 of the studies determined lifetime khat use.

\section{Quality of included studies}

We utilized the Newcastle-Ottawa scale (NOS) with modifications to assess the quality of the studies included in our final analysis. Based on our evaluation all 25 studies were of good methodological quality. The investigators agreed the risk of study selection, outcome measurement, and non-response bias was low. The levels of agreements between the reviewers regarding the levels of bias for studies included in this meta-analysis ranged from moderate to almost perfect (Kappa statistic range 0.50-1 (See Table 2).

\section{The results of a pooled meta-analysis Prevalence of current khat use}

As demonstrated in Table 1, 18/25 (72\%) studies reported the prevalence of current khat use among university students. The total sample size of the participants from the included studies was 19,838. Based on the results of the random-effects method, the pooled prevalence of current khat use was $14.16 \%$ (95\% CI; 11.87-16.81) and we observed a significant heterogeneity $\left(I^{2}=96.14 \% ; \mathrm{Q}=440.16 .13, \mathrm{df}=17, \quad p<0.0001\right)$. The forest plots of the prevalence of current khat consumption were shown in Fig. 2.

The pooled prevalence of current khat use was highest in Saudi Arabia $(18.85,95 \%$ CI 12.31-27.75) and it was 13.59\% (95\% CI 11.02-16.62) in Ethiopia and 13.04\% (95\% CI 10.26-16.44) in Yemen (Table 3). However, in our sensitivity analysis, the difference between the studies was not statistically significant $(P=0.312)$.

In our stratified analysis of included studies by gender we found that the current pooled prevalence of khat use was higher in men $19.26 \%(95 \%$ CI 14.05-25.82) than women $6.41 \%(95 \% \mathrm{CI} 4.12-9.82)$. A significant heterogeneity was found in both men $\left(I^{2}=98.01 ; \mathrm{Q}=553.56\right.$, $\mathrm{df}=11, p<0.001)$ and women $\left(I^{2}=91.96 ; \mathrm{Q}=136.78, \mathrm{df}\right.$ $=11, p<0.001)$. (See Table 3).

\section{Prevalence of lifetime khat consumptions}

As illustrated in Table 1, 21/25 (84\%) studies reported the prevalence of lifetime khat use among university students. The total sample size of the participants from the included studies was 20,718. In our meta-analysis the pooled prevalence of lifetime khat use was 27.31\% (95\% CI; 23.78-31.14\%) and we observed a significant heterogeneity $\left(I^{2}=96.86 \% ; \mathrm{Q}=636.44, \mathrm{df}=20, p<0.001\right)$. The forest plots of the prevalence of lifetime khat use were shown in Fig. 3.

The pooled prevalence of lifetime khat use was highest in Yemen (43.27, 95\% CI 25.31-63.19\%) and it was 24.82\% (95\% CI 21.30-28.72\%) in Ethiopia and 37.32\% (95\% CI 15.74-65.48) in Saudi Arabia (Table 3). A few data were available, and the prevalence of current khat use among university students was very poorly recorded in countries where khat is consumed other than Ethiopia.

In our stratified analysis of included studies by gender we found that the lifetime pooled prevalence of khat use was higher in men $31.47 \%$ (95\%CI 25.73-37.84) than in women $11.79 \%(95 \%$ CI 7.53-18.01). (See Table 3).

\section{The risk of being male and current khat use}

Twelve of the studies provided information regarding the risk of current khat consumption in men and in 


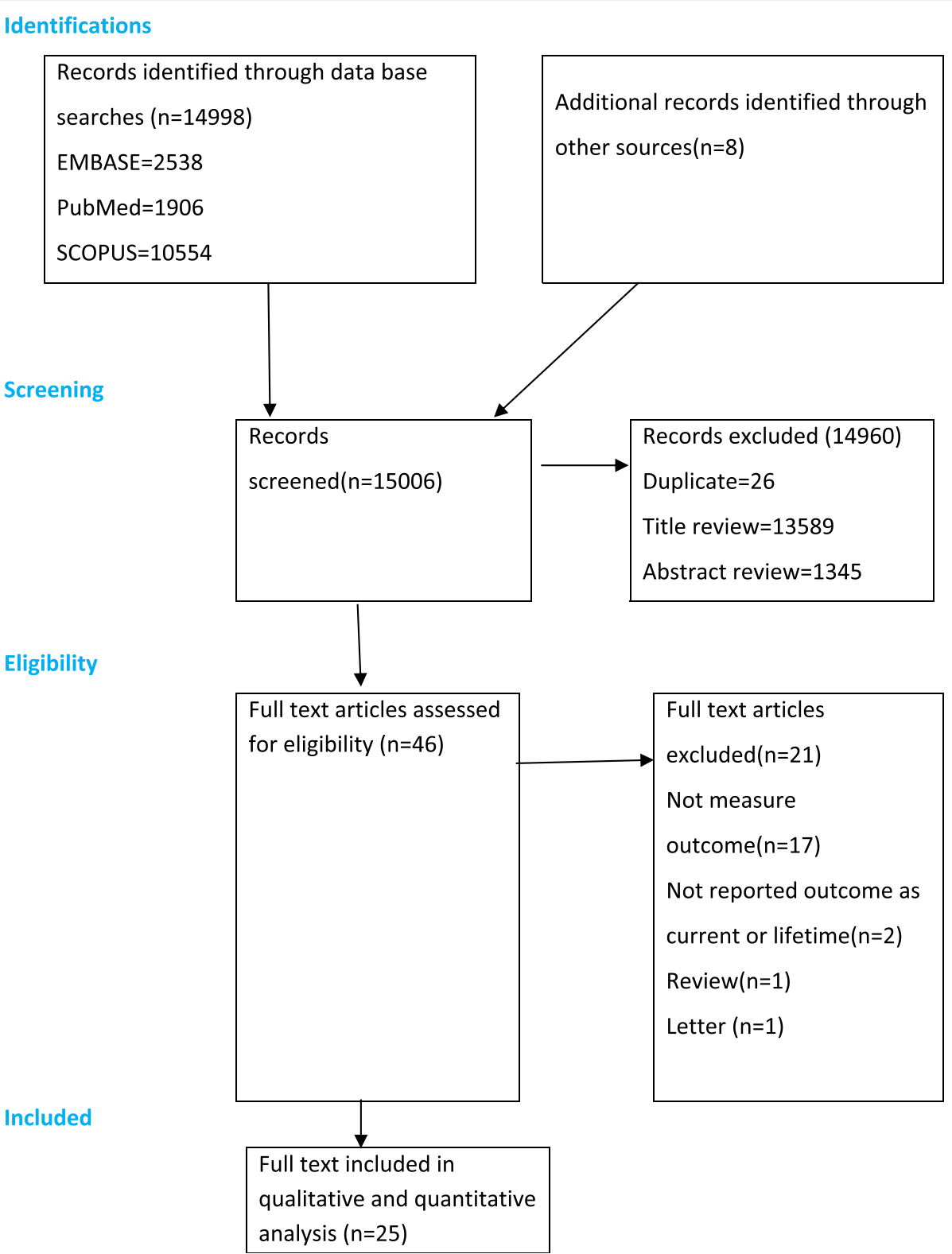

Fig. 1 PRISMA flowchart of review search

women among university students (Table 1 ). The pooled odds ratio (OR) revealed that the odds of current khat use were significantly higher in men compared to women (OR 3.59; 95\%CI 2.01-6.41, $P<0.0001$ ). (See Fig. 4).

\section{The risk of being male and lifetime khat use}

Ten of the studies provided information regarding the risk of lifetime khat use in men and in women university students (Table 1). The pooled odds ratio (OR) demonstrated that the odds of lifetime khat use were significantly higher in men compared with women (OR 3.48; 95\%CI 2.09-5.78, $P<0.0001$ ). (See Fig. 5).

\section{Publication bias}

In our analysis of bias related for the effects of unincluded studies, as provided by funnel plot and Egger's regression tests we found that there no evidence of substantial publication bias for the prevalence of current khat use $((\mathrm{B}=-7.75, \mathrm{SE}=4.95, P=0.137)$ as well as lifetime khat use $(\mathrm{B}=1.17, \mathrm{SE}=3.31, P=0.727)$ among university student. (See Figs. 6 and 7).

\section{Sensitivity analysis}

For the purpose of further investigating the potential source of heterogeneity in the analysis of the prevalence of current and lifetime khat use among university 
Table 1 Characteristics of included studies

\begin{tabular}{|c|c|c|c|c|c|}
\hline Author(year) (reference number) & Sample size & Response rate & Country & Type of use & Outcome (magnitude current and lifetime khat use) \\
\hline Dida N. et.al (2014) [33] & 603 & 97.9 & Ethiopia & Current use & Overall $16.92 \%(n / N=102 / 603)$ \\
\hline \multirow[t]{2}{*}{ Tesfaye G,et al. (2013) [34] } & \multirow[t]{2}{*}{1022} & \multirow[t]{2}{*}{$98.3 \%$} & \multirow[t]{2}{*}{ Ethiopia } & Current use & $\begin{array}{l}\text { Overall } 23.6 \%(n / N=241 / 1022) \\
\text { Men } 28.7 \%(n / N=223 / 777) \\
\text { Women } 7.3 \% n / N=18 / 245)\end{array}$ \\
\hline & & & & Lifetime & $\begin{array}{l}\text { Overall } 41 \%(n / N=419 / 1022) \\
\text { Men } 47.6 \%(n / N=370 / 777) \\
\text { Women } 20 \%(n / N=49 / 245)\end{array}$ \\
\hline \multirow[t]{2}{*}{ Hagos EG, et. Al (2013) [35] } & \multirow[t]{2}{*}{271} & \multirow[t]{2}{*}{$100 \%$} & \multirow[t]{2}{*}{ Ethiopia } & Ever use & Overall 9.2\%(n/N = 25/271) \\
\hline & & & & Current use & Overall $4 \%(n / N=11 / 271)$ \\
\hline Mekonnen T. et.al (2017) [36] & 725 & $97.05 \%$ & Ethiopia & Current use & $\begin{array}{l}\text { Overall } 10.20 \%(\mathrm{n} / \mathrm{N}=74 / 725) \\
\text { Men } 11.83 \%(\mathrm{n} / \mathrm{N}=57 / 482) \\
\text { Women } 7 \%(\mathrm{n} / \mathrm{N}=17 / 243)\end{array}$ \\
\hline Tadesse M. et.al (2014) [37] & 611 & $98 \%$ & Ethiopia & Life time use & $\begin{array}{l}\text { Overall } 41.08 \%(n / N=251 / 611) \\
\text { Men } 44.9(n / N=195 / 434) \\
\text { Women } 31.6 \%(n / N=56 / 177)\end{array}$ \\
\hline \multirow[t]{2}{*}{ Eshetu E.et al. (2006) [38] } & \multirow[t]{2}{*}{564} & \multirow[t]{2}{*}{$89 \%$} & \multirow[t]{2}{*}{ Ethiopia } & Current use & $\begin{array}{l}\text { Overall } 14.36 \%(\mathrm{n} / \mathrm{N}=81 / 564) \\
\text { Men } 17.9(\mathrm{n} / \mathrm{N}=77 / 431) \\
\text { Women } 3 \%(\mathrm{n} / \mathrm{N}=4 / 133)\end{array}$ \\
\hline & & & & lifetime use & $\begin{array}{l}\text { Overall } 31.91 \%(n / N=180 / 564) \\
\text { Men } 37.2(n / N=160 / 431) \\
\text { Women } 14.9 \%(n / N=20 / 133)\end{array}$ \\
\hline Shiferaw D.et al. (2017) [39] & 600 & $92.6 \%$ & Ethiopia & Life time use & Overall 33.3\%(n/N=200/600) \\
\hline \multirow[t]{2}{*}{ Kassa A. et al. (2016) [40] } & \multirow[t]{2}{*}{586} & \multirow[t]{2}{*}{$94.5 \%$} & \multirow[t]{2}{*}{ Ethiopia } & Current use & $\begin{array}{l}\text { Overall } 16.3 \%(n / N=98 / 586) \\
\text { Men } 18.58 \%(n / N=89 / 479) \\
\text { Women } 8.41 \%(n / N=9 / 107)\end{array}$ \\
\hline & & & & Life time use & $\begin{array}{l}\text { Overall } 24.1 \%(n / N=141 / 586) \\
\text { Men } 26.93 \%(n / N=129 / 479) \\
\text { Women } 11.21 \%(n / N=12 / 107)\end{array}$ \\
\hline \multirow[t]{2}{*}{ Gebreslassie M. et.al (2013) [41] } & \multirow[t]{2}{*}{756} & \multirow[t]{2}{*}{$98.7 \%$} & \multirow[t]{2}{*}{ Ethiopia } & Current use & $\begin{array}{l}\text { Overall } 27.9 \%(n / N=211 / 756) \\
\text { Men } 35.6 \%(n / N=158 / 444) \\
\text { Women } 17 \%(n / N=53 / 312)\end{array}$ \\
\hline & & & & Lifetime use & $\begin{array}{l}\text { Overall 28.7\%(n/N = 217/756) } \\
\text { Men 36.5\%(n/N = 162/444) } \\
\text { Women 17.6\%(n/N =55/312) }\end{array}$ \\
\hline \multirow[t]{2}{*}{ Deressa W. et.al (2010) [42] } & \multirow[t]{2}{*}{622} & \multirow[t]{2}{*}{$78 \%$} & \multirow[t]{2}{*}{ Ethiopia } & Lifetime use & $\begin{array}{l}\text { Overall } 14.1 \%(\mathrm{n} / \mathrm{N}=88 / 622) \\
\text { Men } 17.1 \%(\mathrm{n} / \mathrm{N}=77 / 426) \\
\text { Women } 5.6 \%(\mathrm{n} / \mathrm{N}=11 / 196)\end{array}$ \\
\hline & & & & Current use & $\begin{array}{l}\text { Overall } 3.7 \%(\mathrm{n} / \mathrm{N}=23 / 622) \\
\text { Men } 4.9(\mathrm{n} / \mathrm{N}=21 / 426) \\
\text { Women } 1 \%(\mathrm{n} / \mathrm{N}=2 / 196)\end{array}$ \\
\hline Dessie Y. et.al (2013) [43] & 430 & $97.3 \%$ & Ethiopia & Lifetime use & Overall $40 \%(n / N=172 / 430)$ \\
\hline \multirow[t]{2}{*}{ Adere A. et.al (2017) [44] } & \multirow[t]{2}{*}{655} & \multirow[t]{2}{*}{$89.7 \%$} & \multirow[t]{2}{*}{ Ethiopia } & Lifetime use & $\begin{array}{l}\text { Overall } 13 \%(\mathrm{n} / \mathrm{N}=85 / 655) \\
\text { Men } 16.3 \%(\mathrm{n} / \mathrm{N}=74 / 454) \\
\text { Women } 5.5 \%(\mathrm{n} / \mathrm{N}=11 / 201)\end{array}$ \\
\hline & & & & Current use & $\begin{array}{l}\text { Overall } 10.4(n / N=68 / 655) \\
\text { Men } 13 \%(n / N=59 / 454) \\
\text { Women } 4.5 \%(n / N=9 / 201)\end{array}$ \\
\hline \multirow[t]{2}{*}{ Mulugeta Y. et.al (2015) [45] } & \multirow[t]{2}{*}{745} & \multirow[t]{2}{*}{$98.8 \%$} & \multirow[t]{2}{*}{ Ethiopia } & Lifetime use & $\begin{array}{l}\text { Overall } 19.6 \%(n / N=146 / 745) \\
\text { Men } 27.54 \%(n / N=92 / 334) \\
\text { Women } 13.14 \%(n / N=54 / 411)\end{array}$ \\
\hline & & & & Current use & $\begin{array}{l}\text { Overall } 12.73 \%(\mathrm{n} / \mathrm{N}=96 / 754) \\
\text { Men } 18.56 \%(\mathrm{n} / \mathrm{N}=62 / 334) \\
\text { Women } 8.27 \%(\mathrm{n} / \mathrm{N}=34 / 411)\end{array}$ \\
\hline \multirow[t]{2}{*}{ Kebede Y. (2002) [46] } & \multirow[t]{2}{*}{1103} & $87.7 \%$ & Ethiopia & Current use & Overall 17.5\%(n/N = 193/1103) \\
\hline & & & & Lifetime use & Overall 26.7\%(n/N = 294/1103) \\
\hline
\end{tabular}


Table 1 Characteristics of included studies (Continued)

\begin{tabular}{|c|c|c|c|c|c|}
\hline Author(year) (reference number) & Sample size & Response rate & Country & Type of use & Outcome (magnitude current and lifetime khat use) \\
\hline Reda AA et.al (2012) [25] & 1721 & $91,1 \%$ & Ethiopia & Lifetime use & Overall $24.2 \%(n / N=427 / 1721)$ \\
\hline \multirow[t]{2}{*}{ Abdeta et al. (2017) [47] } & \multirow[t]{2}{*}{619} & \multirow[t]{2}{*}{$95.1 \%$} & \multirow[t]{2}{*}{ Ethiopia } & Current use & $\begin{array}{l}\text { Overall } 23.9 \%(n / N=148 / 619) \\
\text { Men } 26.0 \%(n / N=125 / 464) \\
\text { Women } 14.8 \%(n / N=23 / 155)\end{array}$ \\
\hline & & & & Lifetime use & Overall 26.3\%(n/N = 163/619) \\
\hline \multirow[t]{2}{*}{ Astatkie et al. (2015) [48] } & \multirow[t]{2}{*}{1255} & \multirow[t]{2}{*}{97.3} & \multirow[t]{2}{*}{ Ethiopia } & Current use & Overall 11.1\%(n/N = 139/1255) \\
\hline & & & & Lifetime use & Overall $22.8 \%(n / N=286 / 1255)$ \\
\hline \multirow[t]{2}{*}{ Gebrehanna et al. (2014) [49] } & \multirow[t]{2}{*}{3001} & \multirow[t]{2}{*}{$77.5 \%$} & \multirow[t]{2}{*}{ Ethiopia } & Current use & $\begin{array}{l}\text { Overall } 12.7 \%(n / N=380 / 3001) \\
\text { Men } 14.9 \%(n / N=348 / 2328) \\
\text { Women } 4.8 \%(n / N=32 / 673)\end{array}$ \\
\hline & & & & Lifetime use & $\begin{array}{l}\text { Overall } 24 \%(\mathrm{n} / \mathrm{N}=720 / 3001) \\
\text { Men } 27.3 \%(\mathrm{n} / \mathrm{N}=636 / 2328) \\
\text { Women } 12.5 \%(\mathrm{n} / \mathrm{N}=84 / 673)\end{array}$ \\
\hline \multirow[t]{2}{*}{ Alsanosy et al. (2013) [51] } & \multirow[t]{2}{*}{3764} & \multirow[t]{2}{*}{91.80} & \multirow[t]{2}{*}{ Saudi Arabia } & Current & $\begin{array}{l}\text { Overall } 23.1 \%(\mathrm{n} / \mathrm{N}=868 / 3764) \\
\text { Men } 38.5 \%(\mathrm{n} / \mathrm{N}=834 / 2165) \\
\text { Women } 2.1 \%(\mathrm{n} / \mathrm{N}=34 / 1599)\end{array}$ \\
\hline & & & & Lifetime & $\begin{array}{l}\text { Overall } 24.8 \%(\mathrm{n} / \mathrm{N}=935 / 3764) \\
\text { Men } 40.5 \%(\mathrm{n} / \mathrm{N}=876 / 2165) \\
\text { Women } 3.7 \%(\mathrm{n} / \mathrm{N}=59 / 1599)\end{array}$ \\
\hline Quadri et al. (2015) [55] & 476 & $95 \%$ & Saudi Arabia & Lifetime & Overall 51.89\%(n/N = 247/476) \\
\hline Ageely (2009) [27] & 2466 & - & Saudi Arabia & Current use & Overall $15.2 \%(n / N=375 / 2466)$ \\
\hline Kubas Ma et.al. 2015 [53] & 460 & - & Yemen & Current use & $13.04 \%(n / N=60 / 460)$ \\
\hline Alkhadernl et.al (2009) [54] & 100 & - & Yemen & Lifetime use & $54 \%(n / N=54 / 100)$ \\
\hline Dhaifullahet.al (2013) [55] & 360 & - & Yemen & Lifetime use & $33.9 \%(n / N=122 / 360)$ \\
\hline \multirow[t]{2}{*}{ Dachew BA.et al. (2014) [50] } & \multirow[t]{2}{*}{836} & \multirow[t]{2}{*}{$95.8 \%$} & \multirow[t]{2}{*}{ Ethiopia } & Current use & $\begin{array}{l}\text { Overall 13.6\%(n/N = 114/836) } \\
\text { Men } 14.7 \%(\mathrm{n} / \mathrm{N}=79 / 538) \\
\text { Women } 11.7 \%(\mathrm{n} / \mathrm{N}=35 / 298)\end{array}$ \\
\hline & & & & Lifetime use & Overall 17.9\%(n/N = 150/836) \\
\hline
\end{tabular}

students, we performed leave-one-out sensitivity analysis. In our sensitivity analysis, we found that our findings were robust and not dependent on a single study. Our pooled estimated prevalence varied between $11.73 \%(8.37-16.21 \%)$ and $14.38 \%(12.02-.17 .88 \%)$ for the current and 26.28\%(22.92-29.74\%) and 28.41\%(24.81$32.30 \%)$ for lifetime prevalence after deletion of a single study. (See Additional file 1 and Additional file 2).

\section{Discussion}

To the best of our knowledge, this is the first meta-analysis that computed the current and lifetime prevalence of khat consumption among university students. In this meta-analysis, we investigated the prevalence of current and lifetime khat consumptions across 25 cross-sectional studies including a total of 24,136 participants. In addition, we evaluated the existing differences in the risk of khat consumptions between men and women in the last 30 days and consumption of khat in their lifetime among university students. Based on the results from our meta-analysis, the prevalence of both current and lifetime khat consumption was significantly higher in men than in women. We also found that males were 3.59 and 3.48 times more likely than females to have been users of khat in the last 30 days and in their lifetime respectively. Additionally, we found that a considerable proportion of students were users of khat in the last 30 days and in their lifetime. These findings indicate khat consumption is a significant health problem for university students as tobacco and alcohol consumptions [56-58].

In the present meta-analysis, in the included studies the evidence showed an apparent variation by study location (country) and the gender of the participants (male, female). Most of the included studies assessed both current and lifetime khat use and no study was found that determined khat dependence. A few data were available, and the prevalence of khat use among university students was very poorly recorded in countries where khat is commonly consumed other than Ethiopia.

In this meta-analysis, the pooled prevalence estimates of current khat use among university students were $14.16 \%$ (95\% CI; 11.87-16.81). Whereas, the reported prevalence of current khat use ranges between $3.70 \%$ to 27.91\% [41] depending on the study. The sociocultural and economic difference across the different countries 
Table 2 Summary of the quality and agreed level of bias and level of agreement on the methodological qualities of included studies in a meta-analysis based on sampling, outcome, response rate and method of analysis

\begin{tabular}{|c|c|c|c|c|}
\hline \multirow[t]{2}{*}{ Study } & \multicolumn{3}{|c|}{ Overall agreement and precision } & \multirow[t]{2}{*}{ Nos quality (score on 0 to 9 scale) } \\
\hline & Percentage of agreement & Kappa value & Level of agreement & \\
\hline Dida et.al. (2014) [33] & 75 & 0.60 & Moderate & 7 \\
\hline Tesfaye (2013) [34] & 100 & 1 & Almost perfect & 8 \\
\hline Hagos et.al. (2013) [35] & 75 & 0.60 & Moderate & 7 \\
\hline Mekonen et.al. (2017) [36] & 100 & 1 & Almost perfect & 8 \\
\hline Tadesse et.al. (2014) [37] & 100 & 1 & Almost perfect & 9 \\
\hline Eshetu et.al. (2006) [38] & 100 & 1 & Almost perfect & 8 \\
\hline Shiferaw et al. (2017) [39] & 75 & 0.60 & Moderate & 7 \\
\hline Kassa et.al. (2016) [40] & 100 & 1 & Almost perfect & 9 \\
\hline Gebreslassie et.al (2013) [41] & 100 & 1 & Almost perfect & 9 \\
\hline Deressa et.al. (2010) [42] & 100 & 1 & Almost perfect & 9 \\
\hline Dessie et.al. (2013) [43] & 75 & 0.60 & Moderate & 7 \\
\hline Adere et.al. (2017) [44] & 100 & 1 & Almost perfect & 8 \\
\hline Reda AA et.al (2012) [25] & 100 & 1 & Almost perfect & 8 \\
\hline Mulugeta Y. et.al (2015) [45] & 100 & 1 & Almost perfect & 8 \\
\hline Kebede (2005) [46] & 100 & 1 & Almost perfect & 9 \\
\hline Abdeta et al. (2017) [47] & 100 & 1 & Almost perfect & 8 \\
\hline Astatkie et al. (2015) [48] & 100 & 1 & Almost perfect & 8 \\
\hline Gebrehanna et al. (2014) [49] & 100 & 1 & Almost perfect & 8 \\
\hline Alsanosy et al. (2013) [51] & 100 & 1 & Almost perfect & 8 \\
\hline Quadri et al. (2015) [52] & 100 & 1 & Almost perfect & 9 \\
\hline Ageely (2009) [27] & 100 & 1 & Almost perfect & 8 \\
\hline Kubas Ma et.al. 2015 [53] & 100 & 1 & Almost perfect & 9 \\
\hline Alkhader nl et.al (2009) [54] & 75 & 0.50 & Moderate & 6 \\
\hline Dhaifullah et.al (2013) [55] & 75 & 0.60 & Moderate & 7 \\
\hline Dachew BA.et al.(2014) [50] & 100 & 1 & Almost perfect & 9 \\
\hline
\end{tabular}

where the studies were conducted maybe the main reasons for the observed variations in the current prevalence estimates of khat use among university students. In addition, the variability in the magnitude of khat use within the studied countries due to cultural difference as well as accessibility of khat in different areas within a single country might be the other reason for the difference in the observed magnitude. Our pooled prevalence estimate was in line with the general population study prevalence reports from 2011 Ethiopian demographic and health survey data $15.3 \%$ [59]. Our findings were lower than the general population prevalence estimates of the Jazan region of Saudi Arabia (28.7\%\%) [60] and occupational groups in Uganda (20.4\%) [61]. The pooled prevalence of Khat chewing among university students is similar to cigarette smoking prevalence reports from meta-analysis which provided an overall estimation of smoking among students in Iran's universities is $11.6 \%$. However, the estimated prevalence of khat consumption among university students in our review is lower than a systematic review of a finding of the prevalence of alcohol use 31\% among university students [62].

As expected, the estimated current khat consumption rate is higher for males than for females. This meta-analysis provided an estimate of a university student that consumption rates in the last 30 days of $19.26 \%$ for male university students and $6.41 \%$ for female university students. The possible reasons for this significant difference in magnitude of khat consumptions among male and female students may be due to the gender-related biological difference in the brain that possibly resulted in the observed variations in the magnitude of khat use between males and females [63]. The other possible difference might be sociocultural expectations and difference for these population groups. However, the exact reasons for the variation need further investigations. Similar with our finding the prevalence cigarette smoking is also higher in males than females as 


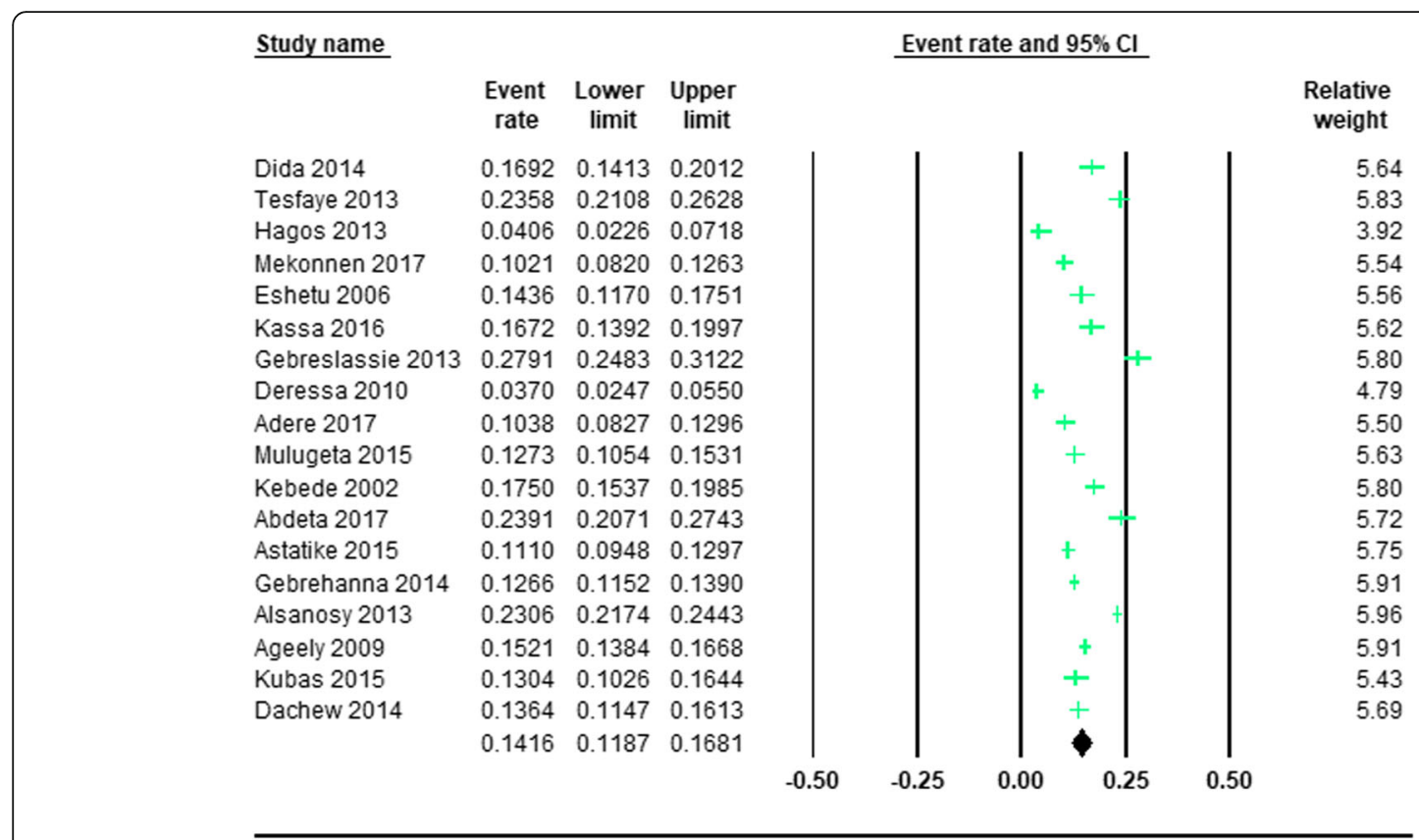

Keys: $I^{2}=96.14, p<0.0001:$ Based on random effect analysis

Fig. 2 Forest plot of current khat use among university students: a meta-analysis

provided by systematic review evidence that resulted the frequency of smoking among the male and female students of Iran is 19.5 and 2.2\%, respectively. The estimated prevalence of current khat use among male students our finding (19.26\%) is similar to the finding of cigarette smoking among male university students (19.5\%) but the estimate of khat consumption among females $(6.41 \%)$ was higher than the estimates of cigarette smoking in female university students (2.2\%).

In our stratified analysis included studies we identified that the pooled prevalence of current khat use among university students was highest in Saudi Arabia (18.85\%) and it was $13.59 \%$ in Ethiopia and $13.04 \%$ in Yemen. This difference may be a sociocultural disparity between the countries. However, our results of the lifetime prevalence estimate khat consumption among university students were highest in Yemen (43.27\%) and it was 24.82\% in Ethiopia and $37.32 \%$ in Saudi Arabia. In our sensitivity, the difference among the studies across the varies countries was not statistically significant.

The results of the present meta-analysis show the pooled prevalence of lifetime khat consumption was

Table 3 Subgroup analysis of the prevalence of khat use among university students based on random effect analysis

\begin{tabular}{|c|c|c|c|c|c|c|c|}
\hline \multirow[t]{2}{*}{ Subgroup } & \multirow{2}{*}{$\begin{array}{l}\text { Number of } \\
\text { studies }\end{array}$} & \multirow{2}{*}{$\begin{array}{l}\text { Type } \\
\text { of use }\end{array}$} & \multicolumn{2}{|l|}{ Estimates } & \multicolumn{3}{|c|}{ Heterogeneity } \\
\hline & & & Prevalence (\%) & $95 \%$ Confidence interval & $\mathrm{I}^{2}(\%)$ & $Q(d f)$ & $P$ value \\
\hline \multicolumn{8}{|l|}{ Sex } \\
\hline Men & 12 & Current & 19.26 & $14.05-25.82$ & 98.01 & $553.56(11)$ & $P<0001$ \\
\hline Women & 12 & Current & 6.41 & $4.12-9.82$ & 91.96 & 136.78(11) & $P<0001$ \\
\hline Men & 10 & Lifetime & 31.47 & $25.73-37.84$ & 96.95 & 294.79(9) & $P<0001$ \\
\hline Women & 10 & Lifetime & 11.79 & $7.53-18.01$ & 95.23 & 188.52(9) & $P<0001$ \\
\hline \multicolumn{8}{|l|}{ Country } \\
\hline Ethiopia & 15 & Current & 13.59 & $11.02-16.62$ & 98.88 & $1243.10(14)$ & $P<0001$ \\
\hline Saudi Arabia & 2 & Current & 18.85 & $12.31-27.75$ & 98.24 & $56.82(1)$ & $P<0001$ \\
\hline Yemen & 1 & Current & 13.04 & $10.26-16.44$ & - & - & - \\
\hline Ethiopia & 17 & Lifetime & 24.82 & $21.30-28.72$ & 96.43 & $447.74(16)$ & $P<0001$ \\
\hline Saudi Arabia & 2 & Lifetime & 37.32 & $15.74-65.48$ & 99.30 & $141.20(1)$ & $P<0001$ \\
\hline Yemen & 2 & Lifetime & 43.27 & $25.31-63.19$ & 92.37 & $13.04(1)$ & $P<0001$ \\
\hline
\end{tabular}




\begin{tabular}{|c|c|c|c|c|c|c|c|c|c|}
\hline \multirow[t]{2}{*}{ Study name } & \multirow[b]{2}{*}{$\begin{array}{c}\text { Event } \\
\text { rate }\end{array}$} & \multirow[b]{2}{*}{$\begin{array}{c}\text { Lower } \\
\text { limit }\end{array}$} & \multicolumn{7}{|c|}{ Event rate and $95 \% \mathrm{Cl}$} \\
\hline & & & $\begin{array}{c}\text { Upper } \\
\text { limit }\end{array}$ & & & & & & $\begin{array}{r}\text { Relative } \\
\text { weight }\end{array}$ \\
\hline Tesfaye 2013 & 0.4100 & 0.3802 & 0.4404 & & & & & + & 4.92 \\
\hline Hagos 2013 & 0.0923 & 0.0831 & 0.1330 & & & & + & & 4.04 \\
\hline Tadesse 2014 & 0.4108 & 0.3724 & 0.4503 & & & & & + & 4.85 \\
\hline Eshetu 2008 & 0.3191 & 0.2820 & 0.3588 & & & & & + & 4.81 \\
\hline Shiferaw 2017 & 0.3333 & 0.2987 & 0.3721 & & & & & + & 4.83 \\
\hline Kassa 2016 & 0.2406 & 0.2077 & 0.2769 & & & & & & 4.78 \\
\hline Gebreslassie 2013 & 0.2870 & 0.2559 & 0.3203 & & & & & + & 4.86 \\
\hline Deressa 2010 & 0.1415 & 0.1182 & 0.1711 & & & & + & & 4.69 \\
\hline Dessie 2013 & 0.4000 & 0.3547 & 0.4471 & & & & & + & 4.77 \\
\hline Adere 2017 & 0.1298 & 0.1081 & 0.1577 & & & & + & & 4.88 \\
\hline Mulugeta 2015 & 0.1936 & 0.1670 & 0.2234 & & & & + & & 4.80 \\
\hline Kebede 2002 & 0.2885 & 0.2413 & 0.2934 & & & & $t$ & - & 4.91 \\
\hline Reda 2012 & 0.2481 & 0.2283 & 0.2691 & & & & & & 4.95 \\
\hline Abdeta 2017 & 0.2633 & 0.2301 & 0.2995 & & & & r & - & 4.81 \\
\hline Astatike 2015 & 0.2279 & 0.2055 & 0.2519 & & & & +1 & & 4.91 \\
\hline Gebrehanna 2014 & 0.2399 & 0.2250 & 0.2555 & & & & & & 4.98 \\
\hline Alsanosy 2013 & 0.2484 & 0.2349 & 0.2625 & & & & & & 4.99 \\
\hline Quardi 2015 & 0.5189 & 0.4740 & 0.5835 & & & & & & 4.81 \\
\hline Alkhader 2009 & 0.5400 & 0.4420 & 0.8350 & & & & & $\rightarrow$ & 4.11 \\
\hline Dhaifullah 2013 & 0.3389 & 0.2918 & 0.3894 & & & & & + & 4.71 \\
\hline \multirow[t]{3}{*}{ Dachew 2014} & 0.1794 & 0.1549 & 0.2069 & & & & + & & 4.81 \\
\hline & 0.2731 & 0.2378 & 0.3114 & & & & & & \\
\hline & & & & -0.50 & -0.25 & 0.00 & 0.25 & 0.50 & \\
\hline
\end{tabular}

Keys: $l^{2}=96.86, p<0.0001$ : Based on random effect analysis

Fig. 3 Forest plot of lifetime khat use among university students: a meta-analysis

27.31\% (95\% CI; 23.78-31.14\%). Our finding was in line with the general population study prevalence reports of khat use from the general population prevalence in of the Jazan region of Saudi Arabia (33.2\%) [60]. However, the estimated prevalence of khat consumption among university students in our review is lower than the results of a systematic review of the prevalence of alcohol use $70 \%$ among young people [62].

As expected, the estimated lifetime khat consumption rate is higher for males than for females. This meta-analysis provided an estimate of university student lifetime khat consumption rates is $31.47 \%$ for male

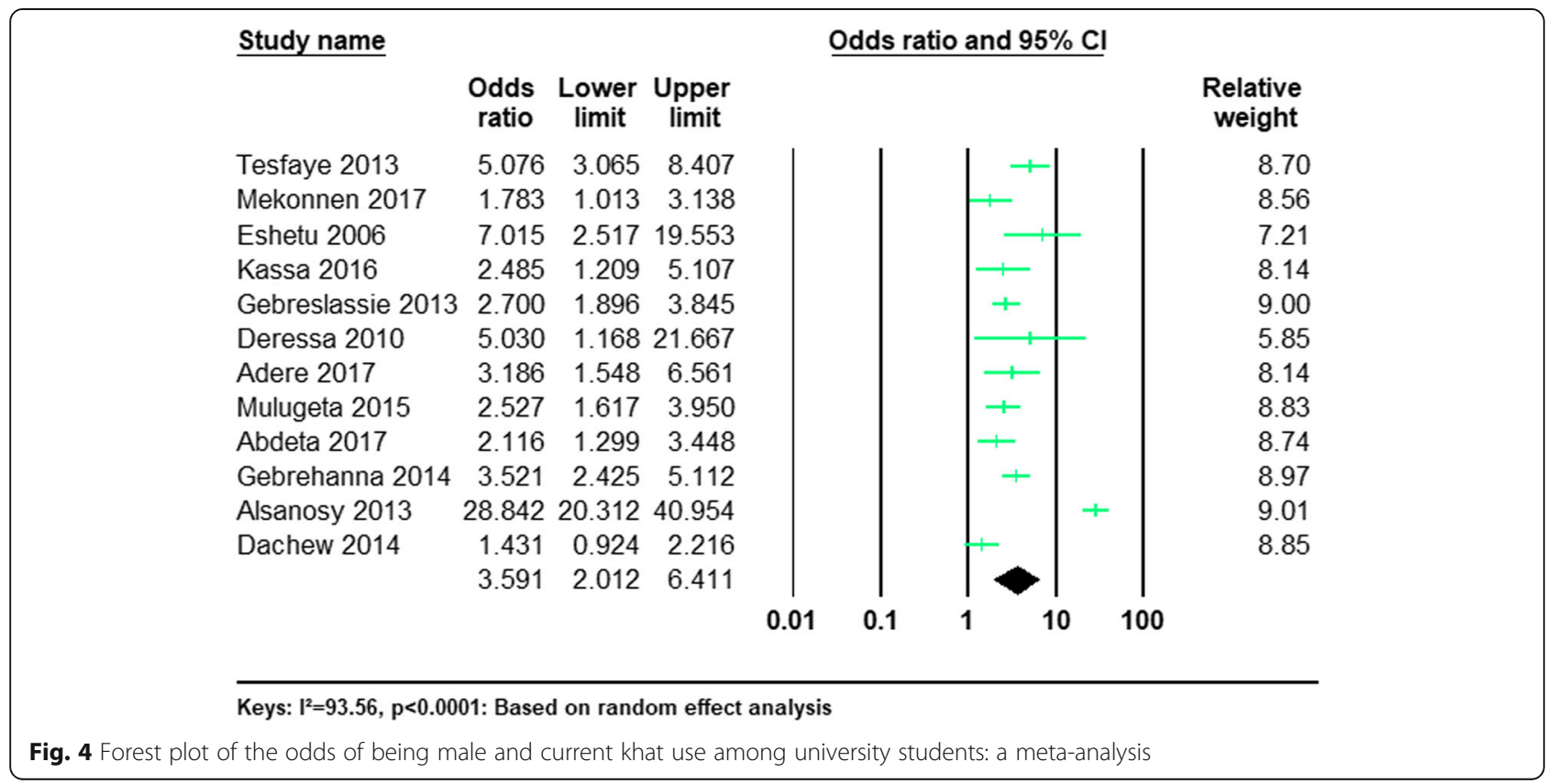




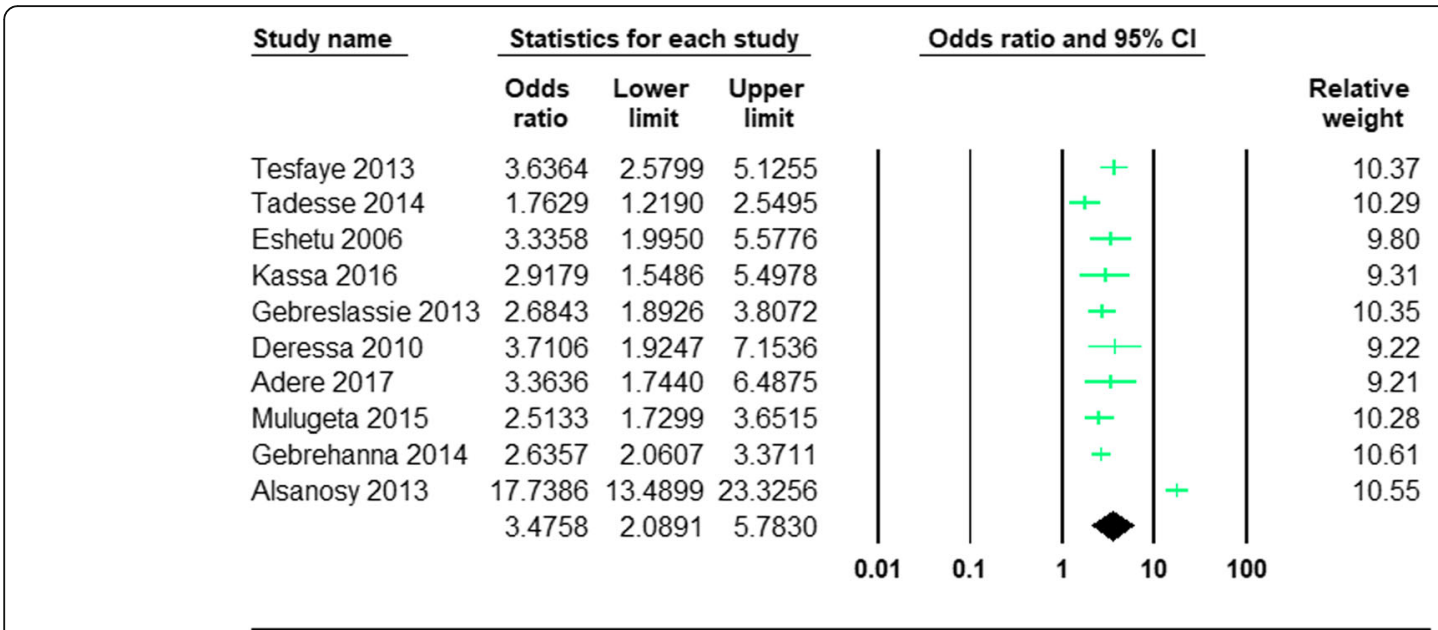

Keys: $I^{2}=94.24, p<0.0001:$ Based on random effect analysis

Fig. 5 Forest plot of the odds of being male and lifetime khat use among university students: a meta-analysis

university students and $11.79 \%$ for female university students. Similar with our finding the prevalence cigarette smoking is also higher in males than females as provided by systematic review evidence that resulted in the frequency of ever alcohol use the male and female students is 53 and $50 \%$, respectively. The estimated prevalence of lifetime khat use among male students our finding (31.47\%) is lower than the finding of ever alcohol use in male university students (53\%) [62]. Similarly, the estimate of lifetime khat consumption among females
$(11.79 \%)$ is lower than the estimates of alcohol use in female university students (50\%) [62].

The results of the meta-analysis also demonstrated that gender was significantly associated with both current and lifetime khat consumptions among university students. Male students were 3.59 and 3.48 times more likely to have been current and lifetime khat users respectively than female students. This an increased risk of khat chewing in men might be due to the cultural norms of the countries. Moreover, gender-related

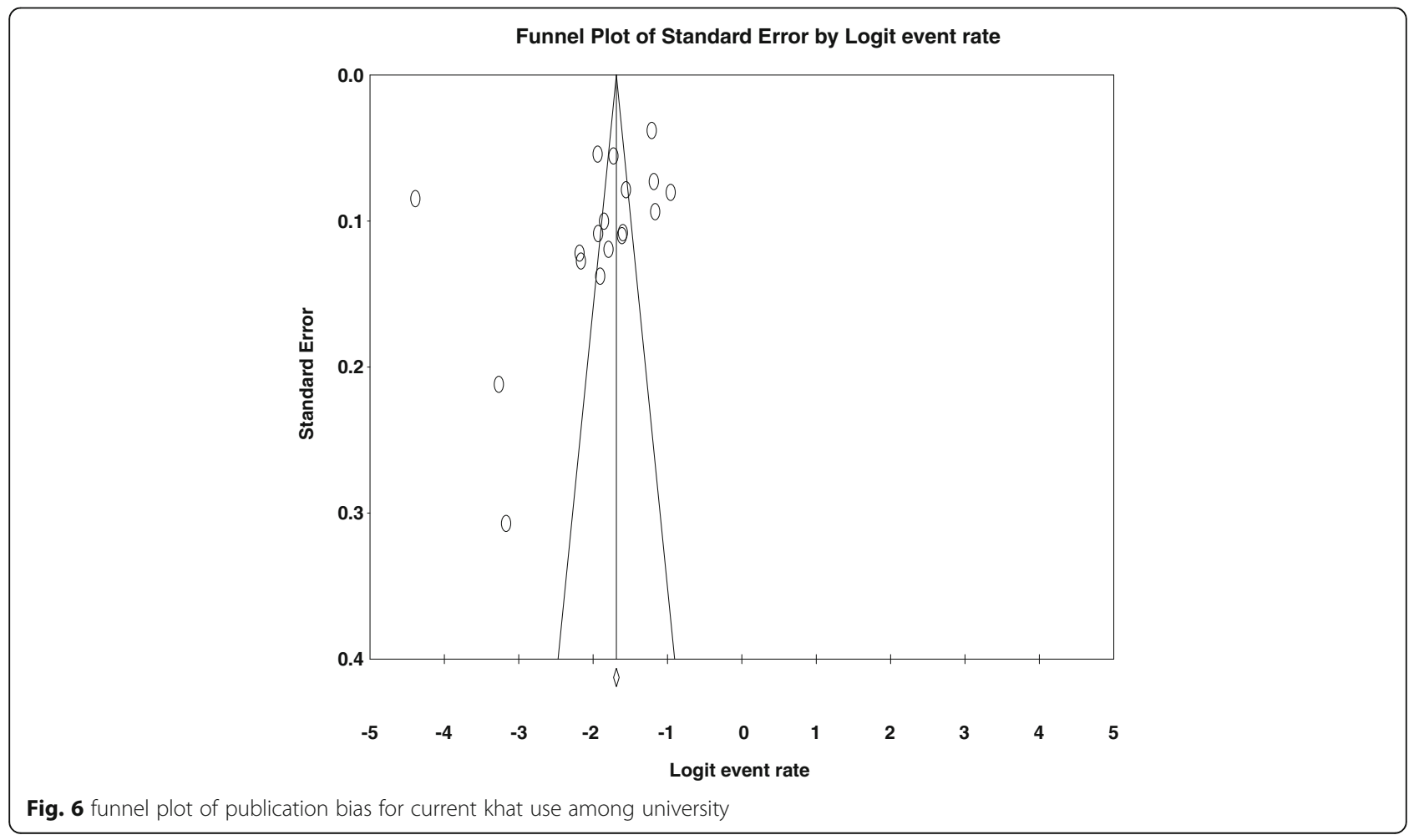




\section{Funnel Plot of Standard Error by Logit event rate}

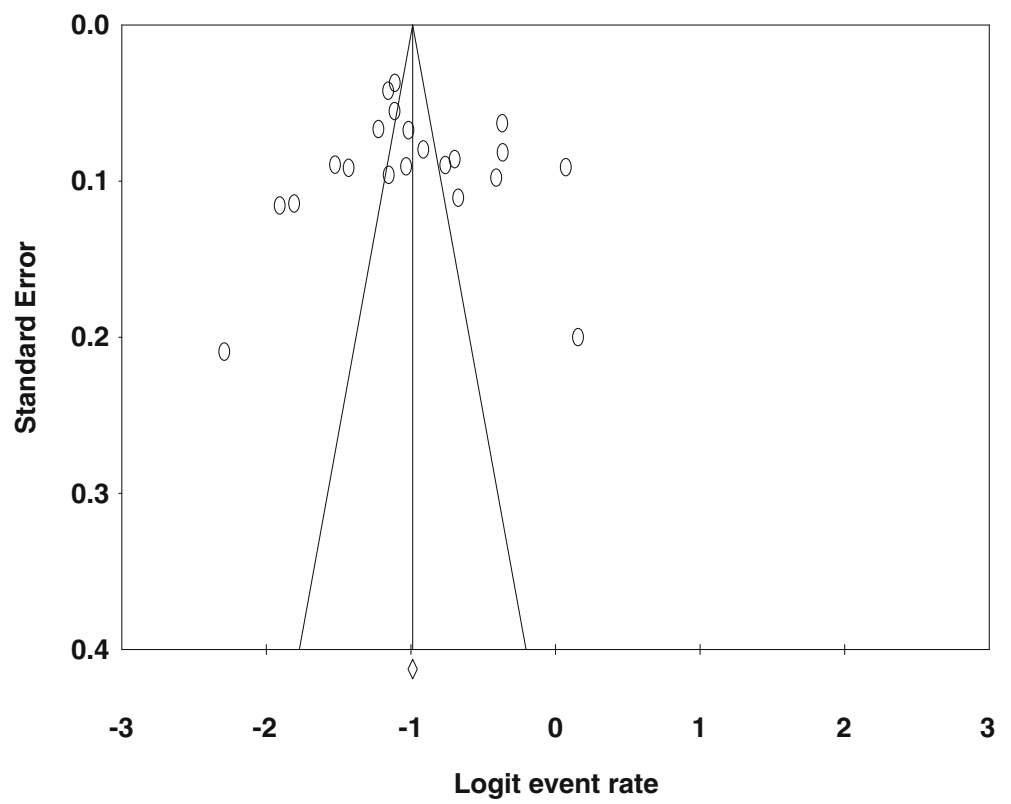

Fig. 7 funnel plot of publication bias for lifetime Khat use among university

variations in the brain might be the other possible reason for the observed difference [63].

\section{Strength and limitation of the study}

The main strength of the present meta-analysis includes: First, we performed an extensive search of electronic databases and scanned references of the remaining articles to include all relevant literature to date; second, we used prespecified search strategy and data extraction was conducted by two independent investigators to minimize possible selection bias; third, a large number of studies were included in this study; fourth, we employed subgroup and sensitivity analysis to find publication bias and the risk of heterogeneity; fifth, we rigorously evaluated the quality of the included studies and the methodological quality of the included articles was generally good based on our assessment. However, we identified an apparent heterogeneity among the studies which we considered as limitations of the present meta-analysis. In addition, we observed that there is apparently a high variability in the magnitude of khat use within the studied countries and that a single prevalence rate per country hides this variance. Finally, since the studies included in this meta-analysis were conducted only in three countries (Ethiopia, Saudi Arabia, Yemen) the findings may not be generalizable to the other population.

\section{Conclusion}

The results of the present meta-analysis show the pooled prevalence of current and lifetime khat consumption among university students were 14.16 and $27.31 \%$, respectively. In our stratified analysis, both the current and lifetime prevalence of khat use were higher in men than in women. We also found that males were 3.59 and 3.48 times more likely than females to be users of khat in the last 30 days and their lifetime respectively.

Even though khat use is banned in Saudi Arabia, both the current and lifetime prevalence estimates of khat consumption among university students were common and comparable with the magnitude in Ethiopia and in Yemen.

Programmes that specifically aimed at increasing awareness and that most motivate reduced khat consumption among university students were recommended. In addition, preventions and interventions programs on khat consumption among university students should be tailored depending on the gender and existing sociocultural and environmental considerations. Future epidemiological studies focusing on the reasons for the observed gender difference in the magnitude of khat consumptions could be conducted. Furthermore, future longitudinal studies focused on incidence and risk factors of khat consumption among university students and studies on better ways to reduce khat consumptions among university students are recommended.

\section{Additional files}

Additional file 1: Sensitivity analysis of prevalence for each study being removed at a time: prevalence and $95 \%$ confidence interval of current Khat use among university. (DOCX 18 kb) 
Additional file 2: Sensitivity analysis of prevalence for each study being removed at a time: prevalence and $95 \%$ confidence interval of Khat use among university. (DOCX $18 \mathrm{~kb}$ )

\section{Abbreviations}

Cl: Confidence Interval; EMBASE: Excerpta Medica Database; OR: Odds Ratio; PRISMA: Preferred Reporting Items for Systematic Reviews and Meta-Analyses

\section{Acknowledgments}

No acknowledgments at this stage.

\section{Funding}

The author declares that there is no funding

\section{Availability of data and materials}

All data generated or analyzed in this study are included in this article.

\section{Authors' contributions}

GA performed the search, data extraction, analyses and draft and approval of final manuscript. MA performed a quality assessment, data extraction, and approved final manuscript. KY participated in revision, discussion and consensus and approved the final manuscript.

\section{Ethics approval and consent to participate} N/A

\section{Consent for publication}

N/A

\section{Competing interests}

The authors declare that they have no competing interests.

\section{Publisher's Note}

Springer Nature remains neutral with regard to jurisdictional claims in published maps and institutional affiliations.

\section{Author details}

${ }^{1}$ Research and Training Department, Amanuel Mental Specialized Hospital, POBOX: 1971, Addis Ababa, Ethiopia. ²Department of Psychiatry, Dilla University, Dilla, Ethiopia. ${ }^{3}$ Department of Psychiatry, Paulo's millennium medical college, Addis Ababa, Ethiopia.

\section{Received: 5 February 2018 Accepted: 29 January 2019}

Published online: 04 February 2019

\section{References}

1. Kalix P. Cathinone, a natural amphetamine. Pharmacol Toxicol. 1992;70(2): 77-86.

2. Odenwald M, Klein A, Warfa N. Introduction to the special issue: the changing use and misuse of khat (Catha edulis)--tradition, trade and tragedy. J Ethnopharmacol. 2010;132(3):537-9.

3. Beckerleg S. Khat special edition introduction. Subst Use Misuse. 2008;43(6): 749-61.

4. Luqman W, Danowski T. The use of khat (Catha edulis) in Yemen: social and medical observations. Ann Intern Med. 1976;85(2):246-9.

5. Al-Motarreb A, Baker K, Broadley KJ. Khat: pharmacological and medical aspects and its social use in Yemen. Phytother Res. 2002;16(5):403-13.

6. Tesfaye F, Byass P, Wall S, Berhane Y, Bonita R. Association of smoking and khat (Catha edulis Forsk) use with high blood pressure among adults in Addis Ababa, Ethiopia, 2006. Prev Chronic Dis. 2008:5(3):A89.

7. Brenneisen R, Fisch H, Koelbing U, Geisshusler S, Kalix P. Amphetamine-like effects in humans of the khat alkaloid cathinone. Br J Clin Pharmacol. 1990; 30(6):825-8.

8. Widler P, Mathys K, Brenneisen R, Kalix P, Fisch HU. Pharmacodynamics and pharmacokinetics of khat: a controlled study. Clin Pharmacol Ther. 1994; 55(5):556-62.

9. Bruno A. Cerebrovascular complications of alcohol and sympathomimetic drug abuse. Curr Neurol Neurosci Rep. 2003;3(1):40-5.

10. Vanwalleghem IE, Vanwalleghem PW, De Bleecker JL. Khat chewing can cause stroke. Cerebrovasc Dis. 2006;22(2-3):198-200.
11. Kulkarni SV, Mughani YAA, Onbol EHA, Kempegowda P. Khat and stroke. Ann Indian Acad Neurol. 2012:15(2):139.

12. Westover AN, Nakonezny PA, Haley RW. Acute myocardial infarction in young adults who abuse amphetamines. Drug Alcohol Depend. 2008;96(1):49-56.

13. Smith H, Roche A, Jagusch M, Herdson P. Cardiomyopathy associated with amphetamine administration. Am Heart J. 1976;91(6):792-7.

14. Kalix P. The pharmacology of khat. Gen Pharmacol. 1984;15(3):179-87.

15. Nencini P, Ahmed AM. Khat consumption: a pharmacological review. Drug Alcohol Depend. 1989;23(1):19-29.

16. Al-Hebshi NN, Al-Sharabi AK, Shuga-Aldin HM, Al-Haroni M, Ghandour I. Effect of khat chewing on periodontal pathogens in subgingival biofilm from chronic periodontitis patients. J Ethnopharmacol. 2010;132(3):564-9.

17. Al-Sharabi AK, Shuga-Aldin H, Ghandour I, Al-Hebshi NN. Qat chewing as an independent risk factor for periodontitis: a cross-sectional study. Int J Dent. 2013;2013.

18. Sadeq-Ali A-M, AlAkhali M. Oral hygiene and periodontal health status among khat chewers. A case-control study. J Clin Exp Dent. 2017;9(5):e629.

19. Rawal SY, Rawal YB, Anderson KM, Bland PS, Stein SH. Plasma cell gingivitis associated with khat chewing. Periodontal Practice Today. 2008;5(1).

20. Degraeve G. Khat-induced psychosis? Tijdschr Psychiatr. 2007;49(10):763-7.

21. Yousef G, Huq Z, Lambert T. Khat chewing as a cause of psychosis. Br J Hosp Med. 1995;54(7):322-6.

22. Sheikh KA, El-setouhy M, Alsanosy R, Yagoub U, Ahmed Z. Khat chewing and health related quality of life: cross-sectional study in Jazan region, Kingdom of Saudi Arabia. Health Qual Life Outcomes. 2014;12(1):44.

23. Al-Sanosy RM. Pattern of khat abuse and academic performance among secondary school and college students in Jazan region, Kingdom of Saudi Arabia (KSA). J Fam Commun Med. 2009;16(3):89.

24. Abafita J, Chala BW, Eba K, Kim K-R, Kim C-S. Khat use and its impact on academic performance: The case of Jimma University, Ethiopia. Educ Res Rev. 2015;10(15):2084.

25. Reda AA, Moges A, Biadgilign S, Wondmagegn BY. Prevalence and determinants of khat (Catha edulis) chewing among high school students in eastern Ethiopia: a cross-sectional study. PLoS One. 2012;7(3):e33946.

26. Louqman W, Danowski T. The use of Khat in Yemen. Social and medical observations. Adv Psychiatr Treat. 2003:9:456-63.

27. Ageely HM. Prevalence of Khat chewing in college and secondary (high) school students of Jazan region, Saudi Arabia. Harm Reduction J. 2009;6(1):11.

28. Reviews, U.o.Y.C.f. and Dissemination. Systematic reviews: CRD's guidance for undertaking reviews in health care. York: University of York, Centre for Reviews \& Dissemination; 2009.

29. Borenstein $M$, Hedges LV, Higgins J, Rothstein HR. A basic introduction to fixed-effect and random-effects models for meta-analysis. Res Synth Methods. 2010:1(2):97-111.

30. Higgins JP, Thompson SG, Deeks JJ, Altman DG. Measuring inconsistency in meta-analyses. BMJ. 2003:327(7414):557.

31. Stang A. Critical evaluation of the Newcastle-Ottawa scale for the assessment of the quality of nonrandomized studies in meta-analyses. Eur J Epidemiol. 2010;25(9):603-5.

32. Landis JR, Koch GG. The measurement of observer agreement for categorical data. biometrics; 1977. p. 159-74

33. Dida N, Kassa Y, Sirak T, Zerga E, Dessalegn T. Substance use and associated factors among preparatory school students in bale zone, Oromia regional state, Southeast Ethiopia. Harm Reduct J. 2014:11(1):21.

34. Tesfaye G, Derese A, Hambisa MT. Substance use and associated factors among university students in Ethiopia: a cross-sectional study. J Addict. 2014;2014.

35. Hagos EG, Asfeha GG, Berihu BA. Prevalence of substance abuse among regular degree health science students in Sheba University College in Mekelle Town, Tigray-Ethiopia. J Neurosci Rural Pract. 2016;7(2):200.

36. Mekonen T, Fekadu W, Mekonnen TC, Workie SB. Substance use as a strong predictor of poor academic achievement among university students. Psychiatry J. 2017;2017

37. Tadesse M. Substance abuse and sexual HIV-risk behaviour among Dilla University students, Ethiopia. Educ Res. 2014;5:368-74.

38. Eshetu E, Gedif T. Prevalence of khat, cigarette and alcohol use among students of technology and pharmacy, Addis Ababa University. Ethiop Pharm J. 2006:24(2):116-24.

39. Shiferaw D, Kinati T, Fufa G, Assefa L. Prevalence Rate of Alcohol Use and Its Associated Factors among Undergraduate Students of Jigjiga University. Age. 18(21):176 
40. Kassa A, Wakgari N, Taddesse F. Determinants of alcohol use and khat chewing among Hawassa University students, Ethiopia: a cross sectional study. Afr Health Sci. 2016;16(3):822-30.

41. Gebreslassie M, Feleke A, Melese T. Psychoactive substances use and associated factors among Axum university students, Axum Town, North Ethiopia. BMC Public Health. 2013;13(1):693.

42. Deressa W, Azazh A. Substance use and its predictors among undergraduate medical students of Addis Ababa University in Ethiopia. BMC Public Health. 2011;11(1):660.

43. Dessie Y, Ebrahim J, Awoke T. Mental distress among university students in Ethiopia: a cross sectional survey. Pan African Medical Journal. 2013;15(1).

44. Adere A, Yimer NB, Kumsa H, Liben ML. Determinants of psychoactive substances use among Woldia University students in northeastern Ethiopia. BMC Res Notes. 2017;10(1):441.

45. Mulugeta Y. Khat chewing and its associated factor among college students in Bahir Dar Town, Ethiopia. Sci J Public Health. 2013;1(5):209-14.

46. Kebede D, Alem A, Mitike G, Enquselassie F, Berhane F, Abebe Y, et al. Khat and alcohol use and risky sex behaviour among in-school and out-of-school youth in Ethiopia. BMC Public Health. 2005;5(1):109.

47. Abdeta T, Tolessa D, Adorjan K, Abera M. Prevalence, withdrawal symptoms and associated factors of khat chewing among students at Jimma University in Ethiopia. BMC Psychiat. 2017:17(1):142.

48. Astatkie A, Demissie M, Berhane Y, Worku A. Prevalence of and factors associated with regular khat chewing among university students in Ethiopia. Subst Abuse Rehabil. 2015;6:41.

49. Gebrehanna E, Berhane Y, Worku A. Khat chewing among Ethiopian University students-a growing concern. BMC Public Health. 2014;14(1):1198.

50. Dachew BA, Bifftu BB, Tiruneh BT. Khat use and its determinants among university students in Northwest Ethiopia: a multivariable analysis. Int J Med Sci Public Health. 2015;4(3):319-23.

51. Alsanosy RM, Mahfouz MS, Gaffar AM. Khat chewing among students of higher education in Jazan region, Saudi Arabia: prevalence, pattern, and related factors. Biomed Res Int. 2013:2013.

52. Quadri MFA, Mahnashi A, Al Almutahhir A, Tubayqi H, Hakami A, Arishi M, et al. Association of awake bruxism with khat, coffee, tobacco, and stress among jazan university students. Int J Dent. 2015;2015.

53. Kubas MA, Wadi M. Comparison of smoking and Khat chewing habits between medical and non-medical female students at UST, Sana'a, Yemen. J Res Health Sci. 2015;15(4):262-5.

54. Al Khader NL, Darwish H. Prevalence of cigarette smoking and khat chewing among Aden university medical students and their relationship to BP and body mass index. Saudi J Kidney Dis Transplant. 2009;20(5):862.

55. Dhaifullah E, Al-Maweri SA, Al-Motareb F, Halboub E, Elkhatat E, Baroudi K, et al. Periodontal health condition and associated factors among university students, Yemen. J Clin Diagn Res. 2015;9(12):ZC30.

56. Davoren MP, Demant J, Shiely F, Perry IJ. Alcohol consumption among university students in Ireland and the United Kingdom from 2002 to 2014: a systematic review. BMC Public Health. 2016;16(1):173.

57. Ham LS, Hope DA. College students and problematic drinking: a review of the literature. Clin Psychol Rev. 2003:23(5):719-59.

58. Haghdoost AA, Moosazadeh M. The prevalence of cigarette smoking among students of Iran's universities: a systematic review and meta-analysis. J Res Med Sci. 2013;18(8):717-25.

59. Haile D, Lakew $Y$. Khat chewing practice and associated factors among adults in Ethiopia: further analysis using the 2011 demographic and health survey. PLoS One. 2015;10(6):e0130460.

60. Mahfouz MS, Rahim B-eEA, Solan YMH, Makeen AM, Alsanosy RM. Khat chewing habits in the population of the Jazan region, Saudi Arabia: prevalence and associated factors. PLoS One. 2015;10(8):e0134545.

61. Ihunwo A, Kayanja F, Amadi-Ihunwo U. Use and perception of the psychostimulant, khat (catha edulis) among three occupational groups in south western Uganda. East Afr Med J. 2004;81(9):468-73.

62. Francis JM, Grosskurth H, Changalucha J, Kapiga SH, Weiss HA. Systematic review and meta-analysis: prevalence of alcohol use among young people in eastern Africa. Tropical Med Int Health. 2014;19(4):476-88.

63. Becker JB, McClellan ML, Reed BG. Sex differences, gender and addiction. J Neurosci Res. 2017;95(1-2):136-47.

\section{Ready to submit your research? Choose BMC and benefit from:}

- fast, convenient online submission

- thorough peer review by experienced researchers in your field

- rapid publication on acceptance

- support for research data, including large and complex data types

- gold Open Access which fosters wider collaboration and increased citations

- maximum visibility for your research: over $100 \mathrm{M}$ website views per year

At BMC, research is always in progress.

Learn more biomedcentral.com/submissions 